\title{
Kehamilan 33-34 Minggu dengan COVID-19 dalam Perspektif Medis, Bioetik, dan Islam
}

\author{
Nasrudin Andi Mappaware ${ }^{1,2}$, Muhammad Mursyid², Erlin Syahril' ${ }^{3}$, Feby Wahyuni Syam ${ }^{4}$ \\ ${ }^{1}$ Fakultas Kedokteran/RS “Ibnu Sina” YW UMI/Bagian Obstetri dan Ginekologi/Universitas Muslim Indonesia \\ ${ }^{2}$ Fakultas Kedokteran/RS “Ibnu Sina” YW UMI/Bagian Bioetika dan Profesionalisme/Universitas Muslim Indonesia \\ ${ }^{3}$ Fakultas Kedokteran/Bagian Radiologi/Universitas Muslim Indonesia \\ ${ }^{4}$ Fakultas Kedokteran/Universitas Muslim Indonesia
}

Korespondensi: ernase@yahoo.co.id, ${ }^{2}$ mursyidmuhammad70@yahoo.co.id

Submisi: 7 November 2020; Revisi: 18 Januari 2021; Penerimaan: 22 Januari 2021

\begin{abstract}
Background: Coronavirus disease 2019 (COVID-19) is a disease that causes a global pandemic and serious public health problem. Until now, knowledge about COVID-19 infection in relation to pregnancy and the fetus is still limited and there are no specific recommendations for handling pregnant women with COVID-19.

Objective: A 28 year old woman, her first pregnancy at 34 weeks (preterm), was admitted to the hospital with complaints of cough, fever and breathlessness. Chest X-ray shows bilateral lung pneumonia. The swab and Rapid test results were positive and were isolated as confirmed COVID-19. Method: Case study

Results and Discussion: Handling according to COVID-19 standards and informed consent for termination of pregnancy with a lung maturation plan. Making decisions on ethical problems and dilemmas with a medical, bioethical and Islamic approach.

Conclusion: Handling and clinical decision making in cases of preterm pregnancy with COVID-19 with various dilemmas apart from medical considerations, requires a bioethical approach and Islamic values.
\end{abstract}

Key words: Pregnancy; COVID-19; preterm; medical; bioethics; Islam

\section{ABSTRAK}

Latar Belakang: Coronavirus disease 2019 (COVID-19) adalah penyakit yang menyebabkan pandemik global dan menjadi masalah kesehatan masyarakat yang serius. Sampai saat ini, pengetahuan tentang infeksi COVID-19 dalam hubungannya dengan kehamilan dan janin masih terbatas dan belum ada rekomendasi spesifik untuk penanganan ibu hamil dengan COVID-19.

Tujuan: Perempuan 28 tahun, kehamilan pertama dengan usia 34 minggu (preterm), masuk rumah sakit dengan keluhan batuk, demam dan sesak. Hasil foto thoraks gambaran pneumonia bilateral paru. Hasil swab dan rapid tes positif dan pasien diisolasi sebagai pasien terkonfirmasi COVID-19.

Metode: Case study

Hasil dan Pembahasan: Penanganan sesuai standar COVID-19 dan informed consent untuk terminasi kehamilan dengan rencana pematangan paru. Pengambilan keputusan terhadap masalah dan dilema etik dengan pendekatan medis, bioetika dan islam.

Kesimpulan: Penanganan dan pengambilan keputusan klinik pada kasus kehamilan preterm dengan COVID-19 dengan berbagai dilema selain pertimbangan medis, diperlukan pendekatan bioetika dan nilai islam.

Kata kunci: Kehamilan; COVID-19; preterm; medis; bioetika; islam 


\section{PENDAHULUAN}

Penyakit Coronavirus 2019 (COVID-19) adalah penyakit infeksi disebabkan oleh novel coronavirus, sekarang disebut severe acute respiratory syndrome coronavirus 2 (SARS-CoV-2). Kemunculan severe acute respiratory syndrome coronavirus 2 (SARSCoV-2) telah menyebabkan Pandemic Global dan menjadi masalah kesehatan masyarakat serius . ${ }^{1}$

Sejak diumumkan pertama kali ada di Indonesia, kasus COVID-19 meningkat jumlahnya dari waktu ke waktu sehingga memerlukan perhatian. Pada prakteknya di masa pandemi, tatalaksana COVID-19 diperlukan kerjasama semua stakholder untuk menanganinya. ${ }^{2}$ Dan diperlukan upaya pencegahan transmisi virus corona dari dan kepada tenaga medis, orang dalam pemantauan (ODP), serta upaya pengobatan terhadap pasien dalam pengawasan (PDP) dan pasien COVID-19. ${ }^{1}$

Sampai saat ini, pengetahuan tentang infeksi COVID-19 dalam hubungannya dengan kehamilan dan janin masih terbatas dan belum ada rekomendasi spesifik untuk penanganan ibu hamil dengan COVID-19. Berdasarkan data yang terbatas tersebut dan beberapa contoh kasus pada penanganan Coronavirus sebelumnya (SARS-CoV dan MERSCoV) dan beberapa kasus COVID-19, dipercaya bahwa ibu hamil memiliki risiko lebih tinggi untuk terjadinya penyakit berat, morbiditas dan mortalitas dibandingkan dengan populasi umum. Efek samping pada janin berupa persalinan preterm juga dilaporkan pada ibu hamil dengan infeksi COVID-19. Akan tetapi informasi ini sangat terbatas dan belum jelas apakah komplikasi ini mempunyai hubungan dengan infeksi pada ibu. ${ }^{4}$

Prinsip-prinsip pencegahan COVID-19 pada ibu hamil, ibu nifas dan bayi baru lahir di masyarakat meliputi universal precaution dengan selalu cuci tangan memakai sabun selama 20 detik atau hand sanitizer, pemakaian alat pelindung diri, menjaga kondisi tubuh dengan rajin olah raga dan istirahat cukup, makan dengan gizi yang seimbang, dan mempraktikan etika batuk-bersin. ${ }^{3}$

\section{LAPORAN KASUS}

Seorang perempuan berusia 28 tahun G1POAO gravid saat ini 34 minggu, masuk RS dengan keluhan batuk dan sesak, KU compos mentis TV: TD 120/80 mmhg, N 88 x/mnt, P 32 x/mnt, Temperatur 38,5 derajat. Auskultasi kedua lapangan paru Ronchi $(+)$, pada pemeriksaan luar TFU $1 / 2$ pusat PX, DJJ $178 \mathrm{x} /$ menit. pada pemeriksaan penunjang Lab: Leukopeni, Limfosit (+), USG, Gravid tunggal, letak kepala, FHR (+), FM (+) Biometri janin sesuai UK 3334 minggu. EFW 2300 gr. Plasenta dan amnion kesan normal. rencana dilakukan pemeriksaan Thorak dengan segala pertimbangan dan setelah informed consent dan Proteksi yang cukup, hasil Thoraks foto gambaran pneumonia bilateral paru. hasil swab dan Rapid tes (+) Corona. pasien diisolasi sebagai pasien positif Corona. penanganan sesuai standar Covid-19 dan informed consent untuk terminasi kehamilan dengan rencana pematangan paru.

\section{HASIL DAN PEMBAHASAN}

Sebagian besar kasus COVID-19 secara global memiliki bukti penularan dari manusia ke manusia. Virus ini dapat dengan mudah diisolasi dari sekresi pernapasan, feses dan fomites. Ada dua rute yang dapat digunakan untuk menyebarkan COVID-19. Pertama adalah melalui kontak dekat dengan orang yang terinfeksi (dalam jarak 2 meter) di mana sekresi pernapasan dapat masuk ke mata, mulut, hidung atau saluran udara. Risiko ini meningkat semakin lama seseorang memiliki kontak dekat dengan orang yang terinfeksi yang memiliki gejala. Rute kedua secara tidak langsung melalui sentuhan permukaan, benda atau tangan orang yang terinfeksi terkontaminasi oleh pernapasan dan kemudian menyentuh mulut, hidung atau mata seseorang. ${ }^{3}$

Wanita hamil tampaknya lebih sulit untuk terinfeksi dibandingkan populasi umum. Kehamilan itu sendiri mengubah sistem kekebalan tubuh dan respons terhadap infeksi virus secara umum, yang kadang-kadang dapat menyebabkan gejala yang lebih parah. Ini akan sama untuk COVID-19. ${ }^{3}$

Sehubungan dengan penularan vertikal (penularan dari wanita ke bayinya antenatal atau intrapartum), bukti yang muncul sekarang menunjukkan bahwa penularan vertikal mungkin terjadi, walaupun proporsi kehamilan dipengaruhi dan signifikansi pada neonatus belum ditentukan. Dua laporan telah menerbitkan bukti IgM untuk 
SARS-COV-2 dalam serum neonatal saat lahir. Karena IgM tidak melewati plasenta, ini mungkin mewakili respons imun neonatal terhadap infeksi in utero. Laporan kasus sebelumnya dari China menunjukkan bahwa tidak ada bukti untuk ini dan cairan ketuban, darah tali pusat, usap tenggorokan neonatal, usap plasenta, cairan genital dan sampel ASI dari ibu yang terinfeksi COVID-19 sejauh ini semuanya dinyatakan negatif terhadap virus. ${ }^{3}$

Ada bukti yang berkembang dalam populasi umum bahwa mungkin ada kohort individu tanpa gejala atau mereka dengan gejala yang sangat kecil yang membawa virus, meskipun kejadiannya tidak diketahui. Kebanyakan wanita hanya akan mengalami gejala pilek/flu ringan atau sedang. Batuk, demam, sesak napas, sakit kepala, dan anosmia adalah gejala lain yang relevan. ${ }^{3}$

Sudah lama diketahui bahwa, sementara wanita hamil tidak selalu lebih rentan terhadap penyakit virus, perubahan pada sistem kekebalan tubuh mereka dalam kehamilan dapat dikaitkan dengan gejala yang lebih parah. Hal ini terutama berlaku menjelang akhir kehamilan. Gejala yang lebih parah seperti pneumonia dan hipoksia ditandai secara luas dijelaskan dengan COVID-19 pada orang tua, orang yang tertekan kekebalannya dan mereka dengan kondisi jangka panjang seperti diabetes, kanker dan penyakit paru-paru kronis. Gejala parah yang sama ini dapat terjadi pada wanita hamil jadi harus diidentifikasi dan ditangani segera. Risiko absolut, bagaimanapun, kecil. $^{3}$

Ada laporan kasus wanita dengan COVID-19 parah pada saat kelahiran yang membutuhkan ventilasi dan oksigenasi membran ekstrakorporeal. Serangkaian kasus dari New York dari 43 wanita yang dites positif COVID-19 menunjukkan pola keparahan penyakit yang serupa dengan orang dewasa yang tidak hamil: $86 \%$ ringan, $9 \%$ parah dan $5 \%$ kritis, meskipun ukuran sampel terlalu kecil untuk menarik kesimpulan yang pasti dan perbandingan tidak dibuat untuk usia, jenis kelamin atau individu yang cocok dengan komorbiditas. Pada saat publikasi, laporan terbaru dari Pusat Penelitian dan Audit Nasional Perawatan Intensif di Inggris melaporkan, dari 2.249 pasien pertama yang dirawat di tempat perawatan kritis dengan diagnosis COVID-19, dua sedang hamil dan sepuluh baru hamil (dalam 6 minggu terakhir). Kasus pneumonia COVID-19 lainnya yang dilaporkan pada kehamilan lebih ringan dan dengan pemulihan yang baik. Pada saat publikasi, kasus kematian ibu belum dilaporkan dalam literatur yang diterbitkan. ${ }^{3}$

Saat ini tidak ada data yang menunjukkan peningkatan risiko keguguran atau kehilangan kehamilan dini sehubungan dengan COVID-19. Laporan kasus dari studi kehamilan awal dengan SARS dan MERS tidak menunjukkan hubungan yang meyakinkan antara infeksi dan peningkatan risiko keguguran atau kehilangan trimester kedua.Tidak ada bukti saat ini bahwa virus ini adalah teratogenik. Namun, bukti terbaru menunjukkan bahwa ada kemungkinan virus tersebut dapat ditularkan secara vertikal, walaupun proporsi kehamilan yang terkena dampak dan signifikansi pada neonatus belum ditentukan. ${ }^{3}$

Ada laporan kasus kelahiran prematur pada wanita dengan COVID-19, tetapi tidak jelas apakah ini iatrogenik dalam setiap kasus, atau apakah ada yang spontan. Kelahiran iatrogenik terutama untuk indikasi ibu yang terkait dengan infeksi virus, meskipun ada bukti kompromi janin dan ketuban pecah dini sebelum persalinan dalam setidaknya satu laporan. ${ }^{3}$

\section{Manifestasi Klinis}

Infeksi COVID-19 dapat menimbulkan gejala ringan, sedang atau berat. Gejala klinis utama yang muncul yaitu demam (suhu $>38^{\circ} \mathrm{C}$ ), batuk dan kesulitan bernapas. Selain itu dapat disertai dengan sesak memberat, fatigue, mialgia, gejala gastrointestinal seperti diare dan gejala saluran napas lain. Setengah dari pasien timbul sesak dalam satu minggu. Pada kasus berat perburukan secara cepat dan progresif, seperti ARDS, syok septik, asidosis metabolik yang sulit dikoreksi dan perdarahan atau disfungsi sistem koagulasi dalam beberapa hari. Pada beberapa pasien, gejala yang muncul ringan, bahkan tidak disertai dengan demam. Kebanyakan pasien memiliki prognosis baik, dengan sebagian kecil dalam kondisi kritis bahkan meninggal. Berikut sindrom klinis yang dapat muncul jika terinfeksi. ${ }^{6}$ 


\section{Diagnosis}

Pneumonia Coronavirus Disease 2019 (COVID-19) adalah peradangan pada parenkim paru yang disebabkan oleh Severe acute respiratory syndrome coronavirus 2 (SARS-CoV-2). Sindrom gejala klinis yang muncul beragam, dari mulai tidak berkomplikasi (ringan) sampai syok septik (berat). ${ }^{6}$

Pada anamnesis gejala yang dapat ditemukan yaitu, tiga gejala utama: demam, batuk kering (sebagian kecil berdahak) dan sulit bernapas atau sesak. Tapi perlu dicatat bahwa demam dapat tidak didapatkan pada beberapa keadaan, terutama pada usia geriatri atau pada mereka dengan imunokompromis. Gejala tambahan lainnya yaitu nyeri kepala, nyeri otot, lemas, diare dan batuk darah. Pada beberapa kondisi dapat terjadi tanda dan gejala infeksi saluran napas akut berat (Severe Acute Respiratory Infection-SARI). Definisi SARI yaitu infeksi saluran napas akut dengan riwayat demam (suhu $\geq 38^{\circ} \mathrm{C}$ ) dan batuk dengan onset dalam 10 hari terakhir serta perlu perawatan di rumah sakit. Tidak adanya demam tidak mengeksklusikan infeksi virus. ${ }^{6}$

\section{Pemeriksaan Fisis}

Pada pemeriksaan fisik dapat ditemukan tergantung ringan atau beratnya manifestasi klinis dinilai dari: Tingkat kesadaran: kompos mentis atau penurunan kesadaran; Tanda vital: frekuensi nadi meningkat, frekuensi napas meningkat, tekanan darah normal atau menurun, suhu tubuh meningkat. Saturasi oksigen dapat normal atau turun; Dan dapat disertai retraksi otot pernapasan. Pemeriksaan fisis paru didapatkan inspeksi dapat tidak simetris statis dan dinamis, fremitus raba mengeras, redup pada daerah konsolidasi, suara napas bronkovesikuler atau bronkial dan ronki kasar. ${ }^{6}$

\section{Pemeriksaan Penunjang}

Pemeriksaan penunjang yang dilakukan di antaranya:

1. Pemeriksaan radiologi: foto toraks, CT-scan toraks, USG toraks Pada pencitraan dapat menunjukkan: opasitas bilateral, konsolidasi subsegmental, lobar atau kolaps paru atau nodul, tampilan ground-glass. Pada stage awal, terlihat bayangan multiple plak kecil dengan perubahan intertisial yang jelas menunjukkan di perifer paru dan kemudian berkembang menjadi bayangan multiple ground-glass dan infiltrate di kedua paru. Pada kasus berat, dapat ditemukan konsolidasi paru bahkan "whitelung" dan efusi pleura (jarang). ${ }^{6}$

2. Pemeriksaan spesimen saluran napas atas dan bawah yang dapat dilakukan adalah pemeriksaan saluran napas atas dengan swab tenggorok (nasofaring dan orofaring) dan pemeriksaan saluran napas bawah (sputum, bilasan bronkus, BAL, bila menggunakan endotrakeal tube dapat berupa aspirat endotrakeal) ${ }^{6}$

3. Pada kasus terkonfirmasi infeksi COVID-19, ulangi pengambilan sampel dari saluran napas atas dan bawah untuk petunjuk klirens dari virus. Frekuensi pemeriksaan 24 hari sampai 2 kali hasil negative dari kedua sampel serta secara klinis perbaikan, setidaknya 24 jam. Jika sampel diperlukan untuk keperluan pencegahan infeksi dan transmisi, specimen dapat diambil sesering mungkin yaitu harian. ${ }^{6}$

\section{Persalinan dan Kelahiran pada Wanita Hamil dengan Covid-19}

Dalam kasus wanita yang terinfeksi pada trimester ketiga, baiknya untuk mencoba menunda persalinan (jika tidak ada indikasi medis lainnya muncul). Pada umumnya, infeksi COVID-19 itu sendiri bukanlah tanda persalinan. Pilihan waktu kelahiran untuk wanita hamil dengan infeksi yang terkonfirmasi bervariasi tergantung pada usia kehamilan, ibu, janin, dan kondisi kelahiran. Keputusan untuk mengakhiri kehamilan berdasarkan pada ibu dan kondisi janin harus dibuat oleh tim. Terminasi kehamilan setelah 37 minggu tampaknya lebih baik setelah tanda-tanda vital ibu telah stabil. ${ }^{11}$

Persalinan normal melalui induksi persalinan dan persalinan per vaginam harus didukung untuk mencegah kelelahan ibu dan menghindari komplikasi bedah yang tidak perlu pada pasien. Jika terjadi syok septik, kegagalan organ akut, atau gawat janin, pelahiran caesar (atau penghentian kehamilan secara legal) harus segera dilakukan. ${ }^{11}$

Manajemen berbasis tim diusulkan untuk mengelola kehamilan yang rentan dan 
positif. Tim harus menyertakan unit klinis yang dioptimalkan yang dapat menyediakan perawatan yang diperlukan. Penting untuk memberikan pengawasan untuk deteksi dini penyakit ibu hamil dan kemampuan untuk memantau komplikasi persalinan (misalnya, kelahiran prematur atau gawat janin). Perubahan dalam pola denyut jantung fisik mungkin merupakan tanda pertama dari penurunan pernafasan ibu. Pertanyaan apakah penghentian kehamilan memiliki manfaat bagi ibu dengan virus masih belum jelas. Oleh karena itu, keputusan mengenai persalinan harus didasarkan pada usia kehamilan janin dan status ibu. ${ }^{11}$

Menurut pengalaman SARS dan MERS, kegagalan pernafasan yang parah dapat terjadi pada kehamilan wanita dan dalam kebanyakan kasus yang parah, ventilasi mekanik mungkin tidak cukup untuk mendukung pengiriman oksigen, di mana studi terbatas menunjukkan peran potensial ECMO dalam kehamilan. RCOG dan RCPCH juga telah membuat rekomendasi untuk perawatan wanita dengan COVID-19 pada tahap persalinan dan menekankan bahwa penundaan penutupan kabel (DCC) tidak direkomendasikan (untuk mengurangi risiko penularan vertikal). Juga, untuk mengurangi penularan virus dari ibu ke bayi, sekresi dan darah dari tubuh bayi harus segera dikeluarkan. ${ }^{11}$

Universitas IImu Kedokteran Isfahan telah memberikan rekomendasi kebidanan di laboratorium sebagai bagian dari proses perawatan dan telah menekankan hal berikut: Tidak ada induksi atau augmentasi persalinan (oksitosin atau sintokrin, misoprostol, dll.). Menerapkan teknik untuk mengurangi nyeri persalinan dan dukungan emosional ibu oleh bidan dalam perawatan setiap ibu (perawatan satu-ke-satu untuk ibu hamil dan bidan dan mengikuti aturan (DR), desinfeksi peralatan dan persediaan oleh layanan bersalin dengan mempertimbangkan ruang isolasi tekanan negatif untuk persalinan yang aman, pemantauan janin yang terus-menerus dalam proses persalinan (karena kemungkinan gawat janin), mengendalikan tanda-tanda vital ibu dengan hati-hati dan setiap jam, pemantauan pernapasan ibu, mencegah kehadiran siapa pun di sisi tempat tidur ibu hamil, menggunakan posisi tegak, duduk, jongkok, dan lateral. ${ }^{11}$
Selain itu, ada penelitian yang mengatakan bahwa di antara 11 wanita nifas, satu pasien melahirkan secara vagina dan 10 pasien melahirkan dengan operasi caesar. Tiga pasien dikirim melalui operasi caesar pada 34-36 minggu karena keyakinan bahwa pengobatan antivirus diperlukan sedini mungkin dalam perjalanan penyakit. Skor apgar dari semua neonatus adalah 8 atau lebih besar, dan tidak ada kasus asfiksia neonatal atau kematian neonatal. Fakta bahwa pasien mampu melahirkan secara nasional adalah bukti bahwa ada peran potensial untuk persalinan alami pada wanita hamil dengan pneumonia COVID-19 ringan. $^{13}$

\section{Analisa Berdasarkan Bioetika}

Bioetika adalah studi interdisipliner tentang masalahmasalah yang ditimbulkan oleh perkembangan biologi dan kedokteran, tidak hanya memperhatikan masalah-masalah yang terjadi pada masa sekarang, tetapi juga memperhitungkan timbulnya masalah pada masa yang akan datang. ${ }^{8}$

Beauchamp dan Childress (1994) menguraikan empat prinsip etika Eropa bahwa untuk mencapai ke suatu keputusan etik diperlukan 4 kaidah dasar moral atau kaidah dasar bioetik. Keempat kaidah dasar moral tersebut adalah: berbuat baik (beneficence), tidak merugikan (non-maleficence), menghargai otonomi pasien (autonomy), dan berlaku adil (justice). ${ }^{8}$

a. Respect for Autonomy (Menghormati Otonomi Pasien)

Yaitu prinsip yang menghormati hak-hak pasien, terutama hak otonomi pasien dan merupakan kekuatan yang dimiliki pasien untuk memutuskan suatu prosedur medis. Prinsip moral inilah informed consent. Pasien harus dihormati secara etik, akan tetapi perlu diperhatikan bahwa dibutuhkan pasien yang dapat berkomunikasi dan pasien yang sudah dewasa untuk dapat menyetujui atau menolak tindakan medis. ${ }^{8}$

Pada pasien ini, diberikan informed concent suatu tindakan medis secara tertulis dalam hal ini dilakukannya isolasi pada pasien karena terinfeksi Covid-19 dengan berdasarkan hasil pemeriksaan fisis dan penunjang serta menjelaskan tujuan dari tindakan ini, prosedur 
pelaksanaan serta manfaat dan kerugian yang mungkin akan terjadi pada pasien. Selain itu, dengan melihat kondisi ibu dan janin dimana telah memasuki trimester 3 , diberikan pula inform concent berupa tindakan terminasi kehamilan dan pematangan paru dengan menjelaskan kemungkinan yang dapat terjadi pada ibu dan janin, tujuan dari tindakan serta prosedur pengerjaannya. Autonomy menyaratkan bahwa pasien harus terlebih dahulu menerima dan memahami informasi yang akurat tentang kondisi mereka, jenis tindakan medik yang diusulkan, risiko, dan juga manfaat dari tindakan medis tersebut. ${ }^{9}$

\section{b. Beneficence (Berbuat Baik)}

Yaitu prinsip moral mengutamakan tindakan yang ditujukan ke kebaikan pada pasien atau penyediaan keuntungan dan menyeimbangkan keuntungan tersebut dengan risiko dan biaya. Dalam beneficence tidak hanya dikenal perbuatan untuk kebaikan saja, melainkan juga perbuatan yang sisi baiknya (manfaat) lebih besar daripada sisi buruknya (mudharat). Dan memandang pasien tidak saja menguntungkan dokternya, serta meminimalisasikan akibat buruk. Point utama dari prinsip beneficence sebenarnya lebih menegaskan bahwa seorang dokter harus mengambil langkah atau tindakan yang lebih bayak dampak baiknya daripada buruknya sehingga pasien memperoleh kepuasan tertinggi. ${ }^{8,9}$

Dalam hal ini dokter telah melakukan yang terbaik kepada pasien dalam upaya pengobatan. Dimana sebelumnya, dokter telah memberikan penanganan yang sesuai dengan standar Covid-19, salah satunya berupa isolasi untuk mencegah penularan lebih lanjut oleh orang sekelilingnya dan untuk menjaga kondisi ibu dan janin. Selain itu, dengan melihat kondisi ibu dan janin, dokter berencana melakukan terminasi kehamilan dan pematangan paru sesuai dengan alur penatalaksanaan pasien dengan Covid-19 hal ini, dimana sebelumnya dijelaskan mengenai rencana tatalaksana ini dengan baik guna menjaga keadaan ibu dan janinnya. c. Non-maleficence (Tidak Merugikan Pasien)

Adalah prinsip menghindari terjadinya kerusakan atau prinsip moral yang melarang tindakan yang memperburuk keadaan pasien. Prinsip ini dikenal sebagai "Primum non nocere" atau "above all do not harm". 8,9

Prinsip yang diterapkan pada pasien ini adalah dilakukannya isolasi untuk menjaga kondisi pasien dan janin, serta rencana terminasi kehamilan yang diharapkan tidak memperburuk keadaan pasien dan mengakibatkan komplikasi lanjutan. ${ }^{8,9}$

d. Justice atau keadilan

Adalah prinsip moral yang mementingkan keadilan dalam bersikap maupun dalam mendistribusikan sumber daya atau pendistribusian dari keuntungan, biaya dan risiko secara adil dimana seorang dokter wajib memberikan perlakuan sama rata serta adil untuk kebahagiaan dan kenyamanan pasien tersebut. Perbedaan tingkat ekonomi, pandangan politik, agama, kebangsaan, perbedaan kedudukan sosial, dan kewarganegaraan tidak boleh mengubah sikap dan pelayanan dokter terhadap pasiennya. Dalam hal ini, dokter dilarang membeda-bedakan pasiennya berdasarkan tingkat ekonomi, agama, suku, kedudukan sosial, dsb. ${ }^{8,9}$

Pada kasus ini, dokter memberlakukan segala sesuatu secara universal artinya dokter memberikan penanganan yang sama pada semua pasien yang menderita penyakit yang sama dalam hal ini pasien dengan pneumonia ec Covid-19 untuk selanjutnya dilakukan terminasi demi kepentingan pasien tanpa memandang unsur SARA, status sosial, dan sebagainya.

\section{Analisa berdasarkan Etika klinik Jonsen - Slegler W}

Pembuatan keputusan etik, terutama dalam situasi klinik dapat juga dilakukan dengan pendekatan yang berbeda yang dikemukakan Jonsen, Siegler, dan Winslade mereka mengembangkan teori etik yang menggunakan 4 topik. ${ }^{8,9}$ 


\begin{tabular}{|l|l|}
\hline MEDICAL INDICATION & PATIENT PREFERENCES \\
Diagnosis & Advance directive \\
Nature of disease & Previous spoken \\
Condition of patient & Previous choices \\
Prognosis & \\
\hline QUALITEnt options & \\
Who decides? & CONTEXTUAL FEATURES \\
What standar? & Social \\
Suffering & Culture \\
Relationships & Legal \\
& Financial \\
\hline
\end{tabular}

\section{a. Medical Indication}

Merupakan indikasi medis berupa diagnosis, perjalanan penyakit, kondisi pasien, prognosis, dan pilihan terapi penialaian aspek indikasi medis ini ditinjau dari sisi etiknya, dan terutama menggunakan kaidah dasar bioetik beneficence dan non-malificence. Adapun beberapa jawaban pertanyaan etik yang selayaknya disampaikan kepada pasien ini pada informed consent. ${ }^{8,9}$

- Isolasi pasien sebagai positif corona serta menjelaskan prosedur dilakukannya tindakan.

- Rencana terminasi kehamilan dengan rencana pematangan paru serta menjelaskan prosedur dilakukannya tindakan dengan tetap memberikan penjelasan mengenai manfaat dan resiko yang mungkin akan terjadi.

- Tujuan pengobatan untuk memperbaiki keadaan pasien, mencegah komplikasi buruk yang dapat muncul.

b. Patient Preference

Kita memperhatikan nilai (value) dan penilaian tentang manfaat dan beban yang akan diterimanya, yang berarti cerminan kaidah autonomy. ${ }^{8}$ Secara rinci jawaban pertanyaan etikanya adalah:

- Pasien secara mental mampu dan kompeten secara legal dalam menyadari dan memahami kondisi klinis yang saat ini dialaminya

- Pasien menyetujui tindakan isolasi dan terminasi kehamilan setelah dilakukan informed consent sebelumnya
- Tentunya pasien telah mengetahui keuntungan serta kerugian dari tindakan yang akan dilakukan serta efek samping yang dapat timbul melalui komunikasi yang baik antar petugas medis dan pasien. ${ }^{8,9}$

c. Quality of life

Merupakan aktualisasi salah satu tujuan kedokteran, yaitu memperbaiki, menjaga atau meningkatkan kualitas hidup insani. Apa, siapa, dan bagaimana melakukan penilaian kualitas hidup merupakan pertanyaan etik sekitar prognosis, yang berkaitan dengan salah satu kaidah dasar bioetik yaitu Beneficence, Nonmalificence, \& Autonomy. ${ }^{8}$ Secara rinci:

- Dampak dari dilakukannya terminasi kehamilan mungkin akan berpengaruh ke bayinya, akan tetapi bila hal ini tidak dilakukan akan memberikan dampak yang lebih merugikan pasien kedepannya.

- Kondisi pasien pasca tindakan terminasi kehamilan diharapkan akan membaik dengan salah-satunya pemberian konseling kepada ibu. ${ }^{8,9}$

d. Contextual Features

Prinsip dalam bagian ini adalah loyalty and fairness. Disini dibahas pertanyaan etik seputar aspek non medis yang mempengaruhi keputusan. Sesuai dengan kasus ini, jawaban dari pertanyaan etikanya adalah: ${ }^{10}$

- Dalam hal ini, tidak ada kendala dari luar yang didapatkan berupa masalah penolakan dari keluarga dan lingkungan pasien yang dapat mempengaruhi pengambilan keputusan pasien. ${ }^{8,9}$

- Tidak ada faktor religius, budaya, dan kepercayaan pada pasien dimana pasien pun menganut agama Islam yang mengajarkan setiap umatnya untuk terus berusaha dan tidak mudah menyerah karena segala penyakit diturunkan bersama dengan obatnya..$^{8,9}$

Adapun berdasarkan pendapat terkait dilemma etiknya, adalah Terminasi kehamilan jika dilihat dari berbagai sudut pandang yaitu medis, hukum, sosial, budaya, ekonomi dan agama merupakan tindakan yang dilarang untuk dilakukan. Tetapi tindakan 
ini menjadi diperbolehkan pada indikasi tertentu yang apabila tidak dilakukan akan menyebabkan hal yang lebih buruk. Sedangkan pada kasus ini, terdapat indikasi yaitu adanya gawat janin dengan djj 178x/menit dan berat 2.300 gr. Selain itu, setelah dilakukan pemeriksaan fisik juga didapatkan ibunya sesak dengan pernafasan 30x/menit. Sehingga, setelah dilakukan berbagai pertimbangan yang menyangkut baik buruknya kondisi ibu dan janin kedepannya, maka dokter merasa perlu untuk dilakukan terminasi dengan sebelumnya dilakukan informed concent kepada pasien dan keluarganya dengan tetap mempertimbangakan keamanan dalam hal ini penggunaan APD (Alat Pelindung Diri).

\section{Analisa Berdasarkan Perspektif Islam}

Secara kaidah bioetik Islam juga didapatkan lima kaidah dasar yang meliputi Kaidah Niat (Qaidah Niyyat), Kaidah Kepastian (Qaidah al yaqiin), Kaidah Kerugian (Qaidah al dharar), Kaidah Kesulitan/ Kesukaran (Qoidah al Masyaqqat), Kaidah Kebiasaan (Qoidah al urf). Sementara itu Kaidah Dasar Bioetika Islam meliputi:

\section{Kaidah Niat (Qaidah Niyyat)}

Prinsip ini meminta dokter agar berkonsultasi dengan hati nuraninya. Terdapat banyak masalah mengenai prosedur dan keputusan medis yang tidak diketahui orang awam. Seorang dokter dapat saja melakukan suatu prosedur dengan alasan yang mungkin masuk akal dari sudut pandang luar, namun sesungguhnya memiliki niatan berbeda dan tersembunyi. Pada kasus ini dokter telah menentukan diagnosis berdasarkan klinis medis yang tampak pada pasien sehingga dokter telah memiliki keputusan untuk memberikan tindakan pada pasien. Pemberian penjelasan tentang kondisi yang dihadapi oleh pasien, dimana pasien harus diisolasi karena terinfeksi Covid-19. Selain itu, diberikan informed concent kepada pasien untuk terminasi kehamilan dan rencana pematangan paru dengan melihat kondisi ibu dan janinnya.

2. Kaidah Kepastian (Qaidah al yaqiin)

Tidak ada yang benar-benar pasti (yaqiin) dalam ilmu kedokteran, artinya tingkat kepastian (yaqiin) dalam ilmu kedokteran tidak mencapai standar yaqiin yang diminta oleh hukum. Meskipun demikian diharapkan dokter dalam mengambil keputusan medis, mengambil keputusan dengan tingkat probabilitas terbaik dari yang ada (evidence based medicine). Termasuk pula dalam hal diagnosis, perawatan medis didasarkan dari diagnosis yang paling mungkin. Pastinya dalam hal pengambilan tindakan medis dokter spesialis telah melihat segala kemungkinan yang terjadi sebelum melakukan tindakan medis. Begitupun dalam kasus ini, dokter mengambil kesimpulan diagnosis berdasarkan anamnesis dan pemeriksaan fisik yang dirujuk berbasis evidence based medicine. ${ }^{10}$

3. Kaidah Kerugian (Qaidah al dharar)

a. Intervensi medis untuk menghilangkan al dharar (luka, kerugian, kehilangan hari-hari sehat) pasien.

b. Tidak boleh menghilangkan al dharar dengan al dharar yang sebanding (al dharar la yuzaal bi mitslihi).

c. Keseimbangan antara kerugian vs keuntungan. Pada situasi intervensi medis yang diusulkan memiliki efek samping, diikuti prinsip bahwa pencegahan penyakit memiliki prioritas yang lebih tinggi ketimbang keuntungan dengan nilai yang sama, dar'an mafasid awla min jalbi al mashaalih. Jika keuntungan memiliki kepentingan yang jauh lebih tinggi daripada kerugian, maka mendapatkan keuntungan memiliki prioritas yang lebih tinggi. Dalam kasus ini, petugas medis telah memaksimalkan keuntungan yang dapat diperoleh pasien dibanding kerugiannya yaitu dengan memberikan penanganan berupa tindakan isolasi dan terminasi kehamilan.

d. Keseimbangan antara yang dilarang dengan yang diperbolehkan. Dokter kadang dihadapkan dengan intervensi medis yang memiliki efek yang dilarang namun juga memiliki efek yang diperbolehkan. Petunjuk hukum adalah bahwa yang dilarang memiliki prioritas lebih tinggi untuk dikenali jika keduanya muncul bersamaan dan sebuah keputusan harus diambil, idza ijtima'a al 
halaal wa al haram ghalaba al haraam al halaal.

e. Pilihan antara dua keburukan. Jika dihadapkan dengan dua situasi medis yang keduanya akan menyebabkan kerugian dan tidak ada pilihan selain memilih salah satu dari keduanya, dipilih yang kurang merugikan, ikhtiyaar ahwan al syarrain. Suatu hal yang merugikan dilakukan untuk mencegah munculnya kerugian yang lebih besar, al dharar al asyadd yuzaalu bi al dharar al akhaff. Dengan cara yang sama, intervensi medis yang memiliki kepentingan umum diutamakan di atas kepentingan individu, al mashlahat al aamah muqoddamat ala al mashlahat al khassat. Individu mungkin harus mendapatkan kerugian untuk melindungi kepentingan umum, yatahammalu al dharar al khaas il dafi u al dharar al aam.

4. Kaidah Kesulitan/Kesukaran (Qoidah al Masyaqqat)

a. Kebutuhan melegalisir yang dilarang. Dalam kondisi yang menyebabkan gangguan serius pada kesehatan fisik dan mental, jika tidak segera disembuhkan, maka kondisi tersebut memberikan keringanan dalam mematuhi dan melaksanakan peraturan dan kewajiban syari'ah. Dalam kasus ini, segala bentuk komplikasi yang dapat terjadi pada pasien harus segera di minimalisir untuk menjaga kesehatan fisik maupun mental pada pasien.

b. Batas-batas prinsip kesulitan: dalam melanggar syari'ah tersebut tidak melewati batas batas yang diperlukan (secukupnya saja).

c. Aplikasi sementara dari prinsip kesulitan. Adanya suatu kesulitan tidak menghilangkan secara permanen hak-hak pasien yang harus direkompensasi dan dikembalikan pada keadaan semula seiring dengan waktu; kesulitan melegalisir sementara dari tindakan medis yang melanggar, berakhir setelah kondisi yang menyulitkan tadi berakhir. Dengan kata lain, jika hambatan telah dilewati, tindakan medis yang dilarang kembali menjadi terlarang. d. Delegasi: mendelegasikan tugas kepada orang lain untuk melakukan tindakan yang membahayakan adalah tindakan yang ilegal.

5. Kaidah Kebiasaan (Qoidah al urf)

Dalam prinsip ini, standar yang diterima secara umum, seperti standard operational procedure (SOP/Protap) untuk perawatan klinis dianggap sebagai hukum dan diperkuat oleh syari'ah. Terkait dengan kasus tersebut, pasien telah menerima upaya yang proporsional dalam tindakan medis dan telah sesuai dengan SOP yang telah ada. ${ }^{2}$

\section{Sudut Pandang Islam terhadap Tindakan Medis}

Tindakan persalinan dengan isolasi merupakan salah satu tindakan dalam bidang obstetric dan ginekologi yang dilakukan dengan tujuan untuk pencegahan infeksi Covid-19 baik bayi ibu maupun janinya. ${ }^{14}$

Segala sesuatu yang Allah ciptakan di muka bumi memiliki fungsi yang akan bermanfaat bagi kelangsungan hidup manusia, termasuk dalam proses pembentukan menusia itu sendiri. Hal ini telah Allah sampaikan dalam Firman-Nya yang tertuai dalam Q.S. Az-Zumar ayat 6: ${ }^{14}$

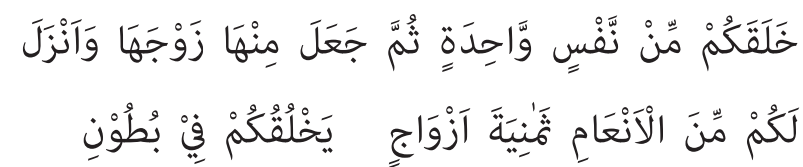

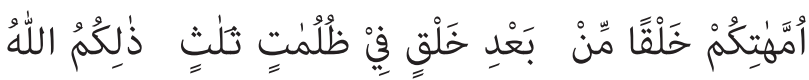

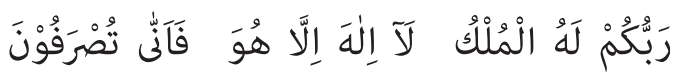

Artinya: Dia menciptakan kamu dari seorang diri kemudian Dia jadikan daripadanya isterinya dan Dia menurunkan untuk kamu delapan ekor yang berpasangan dari binatang ternak. Dia menjadikan kamu dalam perut ibumu kejadian demi kejadian dalam tiga kegelapan. Yang (berbuat) demikian itu adalah Allah, Tuhan kamu, Tuhan Yang mempunyai kerajaan. Tidak ada Tuhan selain Dia; maka bagaimana kamu dapat dipalingkan? (Q.S. AzZumar: 6)

Maksud dari ayat tersebut di atas bahwa Allah telah menciptakan manusia mulai dari Adam a.s. dan dari dirinya juga lah Allah menciptakan istrinya. 
Allah juga menciptakan delapan jenis hewan ternak jantan dan betina diantaranya unta, kambing, sapi dan domba. Allah menciptakan kalian dalam rahim ibu kalian fase demi fase dalam kegelapan perut, Rahim dan selaput yang menutupi kalian dalam Rahim. Itulah Allah yang menciptakan semua ini, tuhan kalian pemilik tunggal segala kerajaan, yang diesakan dengan ibadah dan yang berhak untuk disembah semata, maka bagaimana kalian berpaling dari penyembahan kepada selainNya dari makhlukNya?

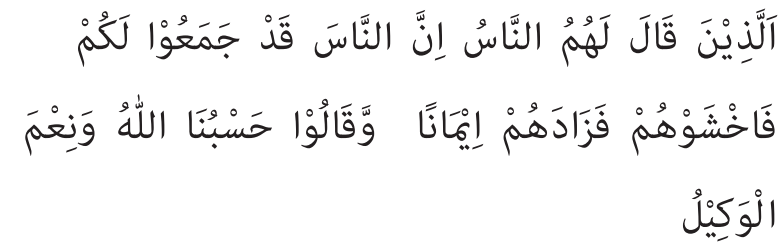

Artinya: (Yaitu) orang-orang (yang mentaati Allah dan Rasul) yang kepada mereka ada orang-orang yang mengatakan: "Sesungguhnya manusia telah mengumpulkan pasukan untuk menyerang kamu, karena itu takutlah kepada mereka", maka perkataan itu menambah keimanan mereka dan mereka menjawab: "Cukuplah Allah menjadi Penolong kami dan Allah adalah sebaik-baik Pelindung". ${ }^{14}$ (Q.S. Ali' Imran: 173)

Orang-orang kafir pernah meneror para sahabat bahwa orang-orang kafir di Mekkah sedang mengumpul- kan pasukannya untuk membumihanguskan Madinah, maka hendaklah kamu takut, tetapi ancaman itu makin menambah kuat iman mereka dan mereka menyatakan: "Cukuplah Allah menjamin kami dan Dia adalah sebaik-baik yang dijadikan andalan." Demikian juga kita bangsa Indonesia sedang dicekam dengan penuh rasa ketakutan dengan merebaknya Virus Corona, maka bertawakallah kepada Allah dan mohon perlindungan kepada-Nya karena Allahlah yang menciptakan Corona, Allah juga yang kuasa untuk menghilangkannya. Jangan pernah mengatakan 'perang' dengan Corona karena terkesan menantang dan menentang kekuasaan Allah, jangan juga 'melawan' Corona, tetapi marilah berlindung kepada Allah agar kita diselamatkan dari bahaya Virus Corona dengan berusaha sekuat tenaga sesuai dengan kemampuan kita.

\section{DAFTAR PUSTAKA}

1. Perhimpunan Dokter Spesialis Gizi Klinik Indonesia. 2020. Protokol klinis dan panduan penyusun menu untuk ODP, PDP Pasien Covid-19 dan Nakes. Versi 1

2. Perhimpunan Dokter Paru Indonesia. 2020. Protokol Tatalaksana COVID-19. Ed. 1: Jakarta

3. Royal College of Obstetricians \& Gynecologist. 2020. Coronavirus (Covid) 19 infection in pregnancy. Published Thursday, 9 April.

4. Perkumpulan Obstetrik \& Ginekologi Indonesia. 2020. Rekomendasi Penanganan Virus Corona Covid-19. Jakarta

5. Kementerian Kesehatan RI. 2020. Pedoman pencegahan dan pengendalian Covid-19. Jakarta.

6. Perhimpunan Dokter Paru Indonesia. 2020. Pneumonia Covid-19 Diagnosis \& Penatalaksanan di Indonesia. Jakarta

7. Wiweko, Budi. 2020. Rekomendasi Penanganan Covid-19 pada Ibu Hamil. Jakarta

8. Mappaware, Nasrudin Andi. Konsep Dasar Bioetika Hukum Kedokteran dalam Penerapan Masa Kini dan Kesehatan sebagai Hak Asasi Manusia. 2007. Makassar

9. Afandi, Dedi. Kaidah Dasar Bioetika dalam Pengambilan Keputusan Klinis yang Etis. Sumatera Barat: Universitas Andalas. 2017. Diakses pada tanggal 1 Mei 2020 dari http://www.jurnalmka. fk.unand.ac.id

10. Zakaria. 2020. Sikap Seorang Muslim dalam Menghadapi Corona. IBN Azka Press. Jawa Barat

11. Leila, Razieh, dkk. 2020. New Coronavirus (COVID-19) Management in Pregnancy and Childbirth. Dept Gynecology\&Obstetric. Iran

12. Marco,Michael,dkk. 2020. Evaluation and Treatment Coronavirus (COVID-19). Download on 6 April 2020

13. Liu,dehan, dkk. 2020. Pregnancy and Perinatal Outcomes of Woman with Coronavirus Disease (COVID-19)Pneumonia. American Journal of Roentgenology

14. Q.S. Az-Zumar ayat 6, Q.S Ali Imran ayat 3

15. Rahamdi, Agus. 2019. Kitab Pedoman Pengobatan Nabi. Jakarta: Wahyu Qalbu

16. Baqi, Muhammad. 2017. Hadits Shahih BukhariMuslim. Jakarta : Gramedia

17. WHO. 2020. Tatalaksana Klinis Infeksi Saluran Pernafasan Akut Berat (SARI) Suspek Penyakit Covid-19 